\title{
1990 VE 2000 SENELERİ ARASINDA TV REKLAMLARINDA ERKEK KIMLIGGININ SUNUMU
}

\author{
REPRESENTATION OF MEN'S IDENTITY IN TELEVISION \\ ADVERTISEMENTS BETWEEN 1990 - 2000 YEARS
}

\author{
МУЖСКАЯ ИДЕНТИЧНОСТЬ В ТЕЛЕВИЗИОННЫХ \\ РЕКЛАМАХ С 1990 ПО 2000 ГОДЫ
}

\section{Hakan YÜKSEL*}

\section{ÖZ}

1990'lı yıllardan itibaren hızlı bir değişim döngüsü içerisine dahil olan dünya, globalleşme olarak kabul edilen bu süreçle birlikte ekonomik ve sosyal yaşamı doğrudan etki altına almaya başlamıştır. Büyük sermaye sahiplerinin dahil olduğu bu küresel döngüde medya alanı da etkiyi hissetmiş ve geleneksel medya araçları için dönüşüm ve teknolojiye entegrasyon durumu kaçınılmaz olmuştur. Nitekim televizyon ve radyo mecralarında özel yayıncılığa geçilmesi sunulan içerikleri değiştirdiği gibi yeni iletişim teknolojileriyle beraber biçimsel formatlarda da değişime gidilmiştir. İçerik olarak izleyiciye sunulan program yapımlarının gerek yapımcı gerekse mevcut televizyon kanalı açısından maddi bağlamda ayakta kalabilmesini sağlayan bir tür olarak ise reklamcılık olgusu ön plana çıkmıştır. Bu olguyu mühim konuma getiren kapital sürecin de etkisiyle reklamcılık alanı televizyon akışı için vazgeçilmez bir unsura dönüşmüştür. Böylece sunum biçimi olarak erkek ve kadın imgeleri ele alınarak hedef kitle profiline göre bir anlayış belirlenmiştir. Zira mevcut çalışmamızda erkek odaklı bir reklamcılık analizi ele alınmış ve on yıllık bir süreç irdelenmiştir. Reklamcılık alanında toplumsal cinsiyet sunumu ele alınırken erkek kimliğinin nasıl temsil edildiğinin incelendiği bu çalışmada 1990 ve 2000 yılları arasındaki televizyon reklamlarının metinsel ve kurgusal bakış açısı tartışılmıştır. Bu bağlamda genel tarama modelinin uygulandığı literatür kısmında televizyon reklamcılığg, medya ve kimlik olguları kavramsal çerçevede araştırılmıştır. Analiz kısmında ise iki televizyon reklamı incelenerek erkek kimliğinin nasıl inşa edildiğinin değerlendirilmesi amaçlanmıştır.

Anahtar Kelimeler: Televizyon Reklamcılığı, Kimlik, Toplumsal Cinsiyet

\section{ABSTRACT}

The world, which has undergone a the cycle of rapid change since the 1990s, has begun to directly influence economic and social life with a process called globalization. In this global cycle, where large capital owners are involved, the media phenomenon is felt to be ineffective and the integration of technology and traditional media tools has become inevitable. As a matter of fact, switching to private broadcasting on television and radio has changed the content presented and formal formats with new communication technologies. Advertisement has been the forefront of the program as a type of program productions that enable the producers to survive in material context with respect to the existing television

\footnotetext{
*Hakan Yüksel, Öğ. Gör., Kafkas Ünv Radyo TV Programc1llğı hakanyuksel25@gmail.com DOI: $10.17498 /$ kdeniz.446351
} 
channel. The advertising industry has become an indispensable element in the flow of television due to the influence of the capital process, which has brought this phenomenon to an important position. Thus, a mentality was determined according to the target audience profile by taking male and female images as a presentation style. In our current study, a male-focused advertising analysis was dealt with and a ten-year process was examined. At this study, how male identity is represented as a gender image in advertising field is discussed from textual and fictive viewpoint of television advertisements between years 1990 and 2000. In this regard, at literature part, general screening model is implemented which is surveyed within notional frame to television advertising, media and identity facts. In the analysis part, two television commercials were examined and it was aimed to evaluate how the male identity was constructed.

Keywords: Television Advertising, Identity, Social Gender

\section{АННОТАЦИЯ}

С начала 1990-х годов мир начал быстро изменятся. Этот процесс и процесс глобализации прямо повлиял на экономическую и социальную жизнь. В этом глобальном цикле, где задействованы крупные владельцы капитала, медиапространство также оказалось под значительным влиянием и для традиционных средств массовой информации стало неизбежным интеграция с новейшей технологией. Таким образом, в телевидении и радио изменился подход к вещанию. Наряду с этим, изменились коммуникационные технологии и форматы самого вещания. Реклама стала одним из основных доходов для существования канала и его программ. Влияние капитала превратило рекламу в незаменимый элемент телевидения. Таким образом, мужские и женские образы определялись в соответствии с профилем целевой аудитории. В нашем исследовании анализируется тема рекламы, ориентированная на мужчин и рассмотривается десятилетний период этого процесса с 1990 по 2000 гг. Основываясь на специфическую литературу, телевизионная реклама, средства массовой информации и случаи идентичности были исследованы в концептуальных рамках. В части анализа были рассмотрены две телевизионные ролики. В нём был показан процесс рекламирования мужской идентичности.

Ключевые слова: Телевизионная реклама, идентификация, гендер.

\section{GíRiş}

Medya ortamının ekonomik bağlamda tam merkezinde yer alan reklamcılık sektörü değişim sürecini hızlı bir biçimde özümseyerek reklam içeriklerini magazinsel boyuta taşıyıp kitleye aktarmaya başlamıştır. Dolayısıyla reklamlardaki erkek ve kadın temsili inşa edilirken geçmiş dönemlerde olduğu gibi belli ve kalıplaşmış sınırlara bağlı kalınmayıp yenilikçi ve değişken içerikler tercih edilmiştir. Ayrıca toplumun beklentisi ikinci plana atılarak reklam içeriklerinde kurgusal formatlara geçilmiş ve ekonomik beklentiler ilk planda tutulmuştur. $\mathrm{Bu}$ doğrultuda gerek erkek kimliğinin temsilinde gerekse kadın modelinin sunumunda reklamın ekonomik yönü önem arz ettiği için toplumsal gerçekliklerden ziyade kitleyi etkileyebilecek kurgusal bir dünya oluşturulmaya başlanmıştır. Kitleyi etkileme noktasında en etkin medya aracının televizyon alanı olduğu değerlendirilerek reklamcılık sektörü genel anlamda bu mecraya yönelmiş ve mali bakımdan oldukça pahalı bir ortam olmasına rağmen televizyon reklamcılığı öne çıkarılmıştır. 
İlgili perspektif çerçevesinde ilerleyen bu çalışmada da reklamın en etkin olarak sunulduğu televizyon mecrası ele alınmış ve alanyazın kısmında reklamlardaki erkek temsilinin televizyon reklamcılığındaki boyutu değerlendirilmiştir. Bu değerlendirmeyi verilerle neticelendirmek için çalışma kapsamında içerik analizi uygulanmış ve 1990'lı yılların iki reklam filmi analiz edilerek erkek temsilinin nasıl inşa edildiği tartışılmıştır. Elde edilen bulgular neticesinde gerek eril kimliğin ekranlardaki sunum şekli öne çıkarılmış gerekse benzer bağlamda kadın kimliğinden ayrılan yönleri anlaşılır vaziyete gelmiştir. Dolayısıyla mevcut çalışma 2000 ve sonrası yıllarda izleyici ile buluşan reklam içerikleri analiz edildiğinde geçmiş döneme ait kaynak niteliği taşıma açısından ve içerik sürdürülebilirliği bağlamında önemli bir dayanak niteliği taşımıştır.

\section{Televizyon Reklamcılığı}

Hem görsel hem de işitsel yetisi dolayısıyla kitle iletişim araçları içerisinde özgün bir durumda bulunan ve bu niteliğiyle izleyiciyi uzun süreli biçimde tarafına çekerek onların davranışsal biçimlerini doğrudan etkileyebilen bir yapıya sahip durumdaki televizyon, kitleler üzerinde oldukça güçlü bir konumdadır. Bunun yanı sıra nitelik olarak her şarta uygun biçimde kitlenin beklentilerine cevap verebilen durumuyla diğer medya organlarına kıyasla daha fazla tercih edilen televizyon aynı zamanda dijital teknolojiler ve uydu yayıncılığının gelişmesiyle beraber sayıca çoğalan kanalların da etkisiyle reklam pastasında önemli bir yer teşkil etmekte ve böylece reklam alanındaki gücüyle izleyiciyi daha fazla etkilemektedir (Taşyürek, 2010:29).

Geleneksel medya araçları içerisinde görsel ve işitsel özellikleri niteliğiyle yer aldığı her dönemde vazgeçilmez bir araç olan televizyon, yeni medya alanına da uyum sağlamakta güçlük çekmemiş ve teknolojik alana kolayca uyum sağlamıştır. Dolayısıyla televizyon dünyasında yaşanan bu gelişmeler reklam sektörü için televizyonu değişilmez bir ortam durumuna getirip kitlelere ulaşma noktasında da televizyonun bu çekici ve cezp edici nitelikleri reklamla olan ilişkisini sürekli hale ulaştırmıştır. Tarih boyunca farklı alanlarda temsil edilen ve giderek değişip gelişen ve bulunduğu çağa uyum sağlayabilen çok yönlü bir reklam olgusundan bahsetmek mümkündür. Teknoloji alanında yaşanan ilerlemeler ile ilişkin bir durum olan bu değişim süreci yeni medya araçlarıyla birlikte reklamcılığı da entegre sürecine dahil etmiştir. Nitekim tarihsel süreçte medya araçlarının en eskisi konumundaki gazeteler kapsamında yer edinen reklamsal faaliyetler daha sonra geleneksel medya araçlarının diğer organları olan radyo, dergi ve televizyonlarda yerini almıştır. Bahsettiğimiz bu entegre süreciyle birlikte ise yeni medya araçlarında görülmeye başlayan reklamlar başta internet olmak üzere medyanın teknolojik dönüşümümdeki yerini almıştır. Böylece gerek broşür, ilan, billboard, pankart ve afişler aracılığıyla gerekse diğer medya kanalları aracılığıyla kitlelere ulaşarak ilerleme kaydeden bir reklam alanı doğmuştur (Apak ve Kasap, 2014:819).

Literatürde birçok farklı tanımı bulunan reklam kavramını açıklayabilecek özellikler şu başlıklar altında sıralayabiliriz (Kocabaş ve Elden, 2004:16):

1. Reklam; hizmet bedeli olarak değerlendirildiğinde belli bir maliyet karşıllı̆gnda gerçekleşen bir olgudur.

2. Amacı kitleyi etkilemek olan reklam, aynı zamanda bir kitle iletişimi olarak kabul edilmektedir.

3. Esas olarak hedef kitleyi ikna edebilmek mantalitesiyle hareket eden reklam, bununla birlikte tüketiciyi bilgilendirme misyonu da üstlenmektedir. 
4. Bir piramit mantığıyla değerlendirildiğinde reklam, reklamı veren şahıs veya kuruluşlardan kitlenin bir parçası olan tüketici konumundaki bireye kadar uzanan bir ileti silsilesidir.

$\mathrm{Bu}$ özellikleriyle birlikte toplum ile tüketim kültürü arasındaki etkileşimi farklı sektörler bağlamında ileten ve bu doğrultuda ortaya çıkabilecek etkileşim boşluğunu dolduran bir mesaj aktarımı olan reklamcılık, kitlenin yaşam tarzını doğrudan etkileyebilen ve yönlendirebilen önemli bir olgu olarak kabul edilmektedir. Nitekim hayatımızı şekillendiren bu olgu farklı iletişim kanallarıyla her ortamda karşımıza çıkmakta ve tercihlerimizi önemli ölçüde etkilemektedir (Williamson, 2001:11).

Aynı zamanda hız döngüsünün önem teşkil ettiği ve sürekli olarak değişen ve gelişen küresel dünyada yaşamın her alanında ve her ortamda reklam ile karşılaşmak mümkündür. Öyle ki kitle iletişim araçlarının yanı sıra sokaklardaki elektrik direğinden ağaç gövdesine yapıştırılan ilâna, toplu ulaşıma araçlarındaki tanıtım afişinden restorandaki broşüre kadar çeşitli mecralarda bu durum yaşanabilmektedir. Dolayısıyla bu sıklıkta etkileşimin yaşandığ reklam faktörünün kitleleri doğrudan etkileme niteliğine ve niceliğine sahip olduğunu göz ard1 etmek mümkün değildir. Nitekim tüketim sektörünün önemli bir dayanağı durumundaki reklamlar sahip olduğu bu geniş ağıyla tüketiciyi etkilemeyi başarmaktadır. Böylece bu unsurlar çerçevesinde değerlendirildiğinde tüketimi arttırabilme yetisiyle etki potansiyelini kanıtlamakta ve ikna kabiliyetini göstermektedir (Özdemir, 2010:104).

Alıcıya ulaşma bağlamında da simgesel bir temsili niteleyen reklam alanı değişen ve aşama kaydeden yapısıyla kitleye sunulmaktadır (Lull, 2001:24). Sunulan reklam içerikleri ele alındığında televizyon reklamları daha etkin yapısıyla bu platformun en güçlü medya aracı olduğunu kabul ettirmektedir. $\mathrm{Bu}$ yapısıyla televizyon reklamlarını farklı kılan unsurlardan birisi mesajın hareketli görüntülerle aktarılmasıdır. Dolayısıyla bu hareketli görüntüler harmanlanarak iletinin etki hacmi geliştirilebilmekte ve metinsel aktarım yerine görsel sunuma ağırlık verilmesi tercih edilmektedir (Bilgin, 2000:108).

Bununla birlikte konvansiyonel ve yeni medya araçlarının da reklamcılık sektörü için çok önemli bir unsur olduğu kabul edilmektedir. Ancak bu medya alanları reklamcılık bağlamında avantajlarının yanı sıra bazı noktalarda dezavantaj da barındırmaktadır. Örneğin geçmişte olduğu gibi günümüzde de vazgeçilmez bir kitle iletişim aracı olan televizyon, hem görsel hem işitsel özellikleriyle birlikte teknolojik çağa uyum sağlayan niteliklere de sahip olarak kitleyi sürekli cezp etmekte ve kaybetmemektedir. Dijital sürece entegrasyon noktasında başarılı olan ve bu niteliğiyle izleyiciyi elinde tutan televizyon mecrası özellikle de çok geniş kitlelere hitap ettiği için reklamcılık sektörü bağlamında en önemli medya aracı konumunda bulunmaktadır. Bununla birlikte geniş kitlelere reklamı ulaştırabilen televizyon aracı dolayısıyla ekonomik olarak da ciddi bir külfeti gerektirmektedir. İşte tam bu noktada reklamcılık açısından zorlu bir süreç başlamakta ve oldukça pahalı olan reklam maliyetlerini karşılamak için büyük çaba sarf edilmektedir. Ayrıca reyting ve süre bağlamında değerlendirilen reklamlar, süre arttıkça maliyet de arttığı için olabildiğince kısa tutularak izleyiciye sunulmak zorunda birakılmakta ve bunun sonucunda reklamda verilmek istenen iletinin algılanabilmesi güçleşmektedir. Yani kapsamlı kitlelere etkin bir biçimde ulaşma noktasında önemli bir avantaj teşkil eden televizyon mecrası mali açıdan oldukça pahalı bir alan olduğu için reklamcılık bağlamında hem fiyat hem de süre açısından olumsuz bir durumu ortaya çıkarmaktadır (Sabuncuoğlu, 2006:42).

Zira ideolojik ve ekonomik olmak üzere iki temel unsuru içeren reklamcılık sektörü bu yapisiyla toplumsal tutum ve sorumluluklara gerek kadın profili gerekse erkek profili üzerinden yarar sağlamakta ve bununla birlikte mali boyut noktasında tüketici sınıfına 
ürünleri lanse ederek küresel sermayeye dahil olmaktadır (Demir, 2006:286). Böylece ekonomik yönünün haricinde kitle psikolojisini de önemsediğini ve gereken rolü üstlenebildiğini kanıtlamaktadır.

Bütün bu yapıları bağlamında nitelik ve misyon olarak hedef kitleyi cezp etme gayreti sarf eden reklam alanının özel amaçları da mevcuttur. Bu amaçları şu başlıklar altında sıralamak mümkündür (Elden, 2004:26):

- Bireysel olarak erişilemeyen durumlarda medyatik yetisini ortaya koyarak her ortamdaki kişilere ulaşabilmek,

- Bu doğrultuda bireysel satışlara da doğrudan destek sağlayabilmek,

- Reklamı ulaştırma noktasında aracı konumunda bulunan kişi veya kurumlar ile olan ilişkileri geliştirerek niteliği ve devamlılığı gerçekleştirebilmek,

- Kitlesel rağbeti sağlamak için medya araçlarının da etkisiyle yeni pazarlara girerek tüketici potansiyelini genişletebilmek,

- Tüm bu amaçlar ile birlikte ön yargilarla mücadele ederek kurumun prestijini koruyabilmek amacı güdülmektedir.

Nitekim reklam olgusunu bir tanıtım aracı olarak sınırlandırmak ve sadece bu çerçeve içerisinde değerlendirmek yeterli değildir. Diğer kitle iletişim organları gibi reklam da erkek ve kadın kimliği temsilinde öncü durumda kabul edilebilir. Öyle ki kimliğin sunumunda ve değişkenliğinde bir dayanak vazifesi gören reklamlar toplumu temsil etme bağlamında bir dağıtım ve değerlendirme mekanizması rolünü de üstlenmektedir (Yavuz, 2000:47).

\section{Medya Ve Kimlik}

Modernizmin ötesi olarak kabul edilen postmodernizm akımı küreselleşmeyle birlikte kitleler üzerinde etkin dönüşümlere yol açmıştır. Oluşan bu dönüşüm kimlik olgusu üzerinde de doğrudan etki göstermiş ve bu doğrultuda küreselleşme bağlamındaki birçok etken kimliklerin oluşumlarında öne çıkmıştır. Geleneksel ve yeni medya araçlarıyla birlikte büyük bir gücü temsil eden medya alanı da kimliklerin tartışılmasında önemli bir yer teşkil eden etkenler arasında yer almaktadır. Nitekim farklı kimlik yansımaları medya araçları aracılığıyla tespit ve tenkit durumuna açık durumda bulunmaktadır. Özellikle toplumsal cinsiyet hususunda medya araçlarındaki kimlik temsilinin sunumu önem arz etmekte ve izlenen bakış açısının bilimsel platformlarda sıklıkla değerlendirilmektedir.

Medya yazılı ve görsel basın içeriklerini kapsayan bir kavram olarak konvansiyonel medya araçlarını bünyesi altında toplamaktadır. Gazete, dergi, radyo ve televizyon medya kapsamındaki kitle iletişim araçları olarak öne çıkmaktadır. Bununla beraber internet gibi yeni medya araçları da medya alanında yer almaktadır (Nalçaoğlu, 2003:44). Kimlik kavramı ise bireyin özgünlüğünün dışa vurulması yani diğer bireylerden farkını ortaya koyarak toplum içerisindeki konumunun belirlenmesini sağlayan bir olguyu temsil etmektedir (Owens, 2006:207). Nitekim bu özgünlükle birlikte birey, kimliği içselleştirerek kendi değer ve yargılarıyla kitle içerisindeki oluşumunu tamamlamaktadır.

Bununla birlikte kimlik olgusu; sosyal kimlik ve kişisel kimlik olarak iki kategoride değerlendirildiğinde $1 \mathrm{rk}$, dil, din ve siyasi aidiyet gibi başlıklar sosyal kimliği oluştururken fiziki, psikolojik ve zihinsel özellikler ile beraber şahsi tercihler kişisel kimliği kapsamaktadır (Turner,2010:18). Dolayısıyla bireyler sosyal kimliğiyle toplum içerisindeki statüsünü dengelerken kişisel kimliğiyle öznel kabiliyetlerini dişa vurarak tutum ve davranışlarını şekillendirmektedir.

Kişisel kimliğin biçimlendirilmesi hususunda medya araçlarının sunumu önemli derecede etki etmektedir. Zira yeni bir rol model arayışında olan bireyler medyadaki kimlik 
temsillerini önemsemekte ve sunulan bu temsilleri medyanın büyülü ortamı neticesinde benimseyebilmektedir. Bu doğrultuda kişisel ve sosyal kimlik özellikleri bireylerin model arayışı bağlamında model içeriğini oluşturmaktadır. Dolayısıyla sosyal öğrenme kuramında da değinilen model alma süreci medyanın kimlik arayışındaki gözlem ve beklentilere etki etmesini ve böylece bireyin model seçimi noktasında hafızada yer alan medyatik kimlikleri kullanıma çıkarmasını ele almaktadır. Neticede kişisel kimliği biçimlendiren bu süreçle beraber kimlik ve model seçimi bağlamında medya ile toplumun etkileşimi sağlanmaktadır (Varol, 2014:308).

Toplumsal süreç içerisinde şekillenen ve oluşumunu tamamlayan kimlik, aynı zamanda toplumsal yapı üzerindeki etki gücüyle bireysel bilinci ve sosyal değerleri etkileyip dönüştürebilmektedir (Berger ve Luckmann, 2008:250). Yine bu noktada da medya organlarındaki kimlik sunumlarının ve bu sunumların hedef kitle üzerindeki vasfının büyük önem teşkil ettiğini belirtmek mümkündür. Öyle ki belirli sembolik sistemler ve algılama pratikleri içeren medya alanı bireye kimlik temsili hususunda öznellik hissi yaşatmaktadır. $\mathrm{Bu}$ öznel durum bireyin benliğinin farkında olmasına katkı sağlamakla birlikte kitle içerisindeki konumunun da ayrımında olmasına yardım etmektedir. Dolayısıyla medyanın etkisiyle oluşan bu sembolik sitemler kimliğin oluşum sürecinde doğrudan belirleyici olmaktadır ve bununla birlikte bireyin toplum içerisindeki kimlik arayışında, kendi rolünü belirleme bağlamındaki düşünce ve beklentilerine cevap bulması kolaylaştırılmaktadır (Woodward, 1997:14 Akt: Varol,2014).

Medyadaki kimlik sunumunda bireylerin çeşitli kimlikler altında temsil edilmesi kitle iletişim araçları aracılığıyla gerçekleşmekte ve bireylerin medyadaki temsili onlara yönelik algıyı da etkilemektedir. Nitekim gerek medya ortamında gerekse gerçek hayatta oluşan bu alg1 medyanın sunum gücünü gösterdiği gibi kimliğin temsil alanının ne kadar önemli olduğunu da öne çıkarmaktadır (Burton, 1995:111). Örneğin ilgiyle takip edilen bir televizyon dizisinde rol model olarak görülen bir karakterin sunduğu kimliğin dışına çıkarak farklı bir kimliğe bürünmesi, o modele olan algıyı ve bakış açısını değiştirdiği gibi temsil ettiği kimliğin de sorgulanmasına zemin hazırlamaktadır.

Nitekim geleneksel ve yeni medya araçlarının kitle üzerinde oldukça etkili bir gücü bulunmakta ve sunum içeriklerindeki karakterler ve kimlikler kitleleri ciddi derecede etkilemektedir. Bunun yanı sıra medya araçlarında paylaşılan temsillerin belli bir fikir ve kesimi temsil etme durumu da söz konusu olduğunda sunulan kimliğe olan bağl1lık ve beklenti bir kat daha artmaktadır. Böylece ekrandaki ya da herhangi bir medya ortamındaki kimlik sunumunun etkisi bireyin gerçek yaşamını doğrudan etkilemekte ve taklitten de öte bir durum ortaya çıkmaktadır. Medyadaki bu temsilleri özümseyen ve kendi yaşamıyla harmanlayarak modelin tarzına uygun bir tarzı oluşturan birey, bu kimlik özelliklerine entegre olmaya çalışmaktadır. Neticede kendi benliği dışına çıkarak medyadaki temsillerin yaşadığı gibi yaşamaya gayret gösterip bilinçaltındaki sanal dünyayı realiteye dönüştürdügünü düşünmektedir (Varol, 2014:309). Hâlbuki kimlik esas olarak bir öz duruş ve öz benliktir. Yani bir insanı diğer insanlardan ayırt eden özellikleri kapsayan ve bu özellikler ile birlikte hayattaki rolünü benimsemesini sağlayan içeriklerdir.

Kimlik kavramıyla ilgili literatürde birçok içerik yer almaktadır. Kemal Karpat'a göre; "kimlik, kişinin içinde yaşadı̆̆ çeşitli gruplarla olan ilişkilerini ve bu gruplara olan ödev, hak ve bağlllık derecelerini tayin etmektedir. Bu hak ve bağlllıklar, kişinin ve toplulukların varlıklarını savunmalarını ve gelişmelerini sağladığı için her şeyden evvel kişiler arası beraberlik ve bilhassa dayanışma amacı güderler." (Karpat, 1987:23) Ancak Karpat'ın kimlik ile ilgili bu tespiti medyadaki modeller bağlamında değerlendirildiğinde 
dayanışmadan ziyade yalnızca etkileme ve benimsetme mantalitesinin var olduğu görülmektedir. Öyle ki etkilenen kitle kendisine model seçtiği temsilleri özümseyerek sanal bir hayata hapsolmaktadır. Ve böylece esas niteliğinden uzaklaşan kimlik olgusu medya ortamında farklı kalıp yargılara aktarımını sürdürmektedir.

"Kimlik, zamanın akışına göre özne veya objeyi etkileyebilecek değişikliklerin dışında kalan sabit işaret noktalarının korunması ve sürekliliği kavramına bağlıdır. İkinci olarak kimlik, ayırt etme gücü için zorunlu bütünleştirici tutarlılı̆̆l, birliği ve ayrılmış bir durumda varoluşu sağlayan bir sınırlandırmaya da uygundur. Nihayet kimlik, iki öğe arasında mümkün ilişkilerden biridir ve ancak bu ilişki sayesinde iki öğe arasında var olan ve özdeş olarak tanınmayı sağlayan mutlak benzerlik saptanabilir.” (Bilgin, 1994:229)

Bireyin kişisel ya da kitlesel kimlik arayışı, küresel dünyada sağlam bir dayanak arayışı olarak nitelendirilebildiği gibi kimliği etkileyen yan faktörlerden sıyrılmayı da gerekli kılmaktadır. Bizi özgün kılan kimlik olgusu bu arayış sürecinde birey ve bireyin dünyasını anlamlı hale getirmektedir (Harwey, 1999:337). Bireyin dünyası çeşitli stereotipleri barındırdığı için kendi çizgisini seçen bireyler bu çeşitlilik arasında kimlik bunalımından çıkarak özümsediği modeli kendi benliğine uyarlayıp toplum içerisindeki temsilini gerçekleştirmektedir. Böylece öz duruşuyla ve özgün karakteriyle bir birey, medya gibi yan faktörlere rağmen esas kimliğini öne çıkarmayı başarabilmektedir.

\section{Reklamcılık Alanında Erkek Kimliğinin Temsili}

Etki alanı olarak oldukça güçlü olan, her ortamda erişilebildiği gibi her kesime de hitap eden, yeni medyaya entegre olduğu için konvansiyonel medya kadar yeni medya alanının da güçlü bir organı olan ve özellikle de kitleleri yönlendirme bağlamında medyanın öncü kollarından biri olan televizyon mecrası reklamcılık sektörü için vazgeçilmez bir alanı teşkil etmektedir (Dündar, 2012:127). Bu sebeple toplumsal cinsiyet bağlamındaki kimlik inşası reklam bağlamında genel olarak televizyon aracılığıyla kitleye ulaştırılmaktadır. Ve gerek erkek gerekse kadın figürünün sunumu televizyon reklamlarında daha fazla incelenmekte ve tartışılmaktadır. Televizyonu reklam için önemli kılan başlıca etmen izleyici üzerindeki vazgeçilmez cazibesi olarak kabul edilmektedir. Çünkü her ne kadar sunulan öğelerin belli bir kısmı gerçekdışı ve kurgusal olsa bile izleyici bu durumu dahi benimsemekte güçlük çekmemekte ve toplumsal alan ile bağdaştırmaya çalışmaktadır (Uslu, 2000:13). Reklam sunumlarında da öncü hedef izleyiciyi cezp etmek olduğu için reklam ve televizyon ilişkisi kaçınılmaz hale gelmekte ve mali olarak pahalı olsa bile hedefe ulaşma noktasında televizyon, reklam sektörü için büyük bir önem teşkil etmektedir.

Medya araçları toplumsal cinsiyet olgusunu çeşitli sunumlarında farklı temsillerle dışa vurmaktadır. Reklamlar da bu dışavurumun küçük ama etkili bir parçasını teşkil etmekte ve gerek erkek profilini gerekse kadın profilini içeriğinde etkin bir biçimde işlemektedir. $\mathrm{Bu}$ içerik bağlamında en sık tercih edilen modeller ise erkeğin aile reisi kadının da ev hanımı olduğu durumlar olarak karşımıza çıkmaktadır. Nitekim toplumsal yaşamın beklentileri noktasında erkeğe evine bakmakla yükümlü olan sorumlu bir eş ve baba imajı yüklenirken kadına ise genel olarak mutfak işleri ve çocuk ihtiyaçlarında öncü olan bir eş ve anne modeli biçilmektedir (Özdemir, 2010:103). Reklam içeriklerinde öne çıkarılan bu durum esas olarak televizyon ve sinemada daha fazla ele alınmakta ve her ne kadar son yıllarda bu imajın dışına çıkılsa da erkek ve kadının temsil nitelikleri bu çizgide sürmeye devam etmektedir. Reklamlarda aile ve çocuk ilişkisi bağlamında erkek ve kadın modeli farklı olarak aktarılmaktadır. Bunun yanı sıra kadın ve çocuk ilişkisi ele alındığında genelde çocuğun sunumu bebek veya küçük çocuk olarak temsil edilirken erkek ve çocuk ilişkisinde ise durum biraz daha farklılaşmaktadır. Yaşça daha büyük çocukların tercih 
edildiği bu reklamlarda baba rolünde karşımıza çıkan erkek kimliği genellikle çocuklarına bir şeyler öğretirken ve onlarla spor yaparken gösterilmektedir (Kaufman, 1999:439). Bu noktada da kadına şefkatli bir anne rolünün erkeğe ise öğretici ve kudretli bir baba rolünün biçildiği ortaya çıkmaktadır.

Toplumsal algının erkek ve kadına atfettiği imaj, reklamlar aracılığıyla sunulurken aynı zamanda toplumsal cinsiyetin temsili bağlamında bireylerin kimlikleri de inşa edilmektedir. Reklam içeriklerindeki temsillerin ortaya çıkarılması da bu kimliklerin aktarılmasıyla bağlantılı olup kitlelere erkek ve kadın modelinin rol bağlamındaki çeşitli biçimleri sunulmaktadır. Zira tüketici olarak algılanan kadın ve erkek profili bu sunumlar neticesinde toplumun öngördüğü imajı sergilemek durumunda kalmaktadır (Timisi, 2004:36). Dolayısıyla temel amacı hedef kitleyi etkilemek olan reklamcılık sektöründe toplumun güncel nabzı takip edilerek çağa uygun kimlik inşasına önem verilmekte ve bu doğrultuda beklentileri karşılayabilecek sunumlarla erkeksi ve kadınsı modeller içerikte kullanılmaktadır. Küresel dünyada her alanda olduğu gibi değişen ve gelişen medya organları da bu içerikleri sunma noktasında teknolojinin imkânlarını kullanarak erkek ve kadın temsilini kitleye en etkin biçimde aktarmaktadır. Bu doğrultuda toplumu iyi takip eden reklam sektörünün ehil kişileri erkek ve kadın sunumunu en doğru ve en etkin bir biçimde yapabilmek için sosyal kimliği temsil eden tutum, davranış, inanç ve fikirleri değerlendirmekte ve bu bağlamda içerik oluşturularak sunum gerçekleşmektedir (Sabuncuoğlu, 2006:133). Her ne kadar medya organları kitleyi etkileme ve yönlendirme hususunda başarılı olsa da toplumun mantalitesine aykırı olan içerik sunumları önemli bir kaos oluşturabileceği için kitleyi dizginleyecek aktarımların ve kimlik temsillerinin paylaşımı, gerekli bir hamle olarak kabul edilmektedir. Bu hamle gerçekleşirken de özellikle inanç ve geleneklerin esas alınması büyük önem teşkil etmektedir.

Medyanın en etkin araçlarından birisi olan televizyon ekranlarındaki reklam sunumlarında her dönemde olduğu gibi erkek temsili ele alınırken güç teması ön plana çıkarılmaktadır. Nitekim reklam içeriklerinde mahrem odası, spor alanları ve iş yerleri başta olmak üzere çeşitli ortamlarda eril gücün vurgulandığı görülmektedir (Deana, 2002:1). Bu algının temelinde toplumun erkek kimliğine biçtiği güç simgesinin var olduğunu söylemek mümkündür. Son yıllarda erkek sunumunda daha entelektüel ve zarif bir erkek imajı verilmeye çalışılsa da genel olarak güç ve sorumluluk temaları erkek profiliyle özdeşleşmektedir. Ve bu durum her ülkede, her toplumda bu şekilde değerlendirilmektedir. Nitekim televizyonun özel yayıncılık ile birlikte çok etkin olduğu yıllarda televizyon reklamlarında erkek temsili ele alınırken gücü simgeleyen niteliklere yer verilmesi adeta izleyiciye bu niteliklerin sıklıkla hatırlatılması durumunu ortaya çıkarmıştır (Roland, 1986:202). İlk yıllarda olduğu gibi bu imajın sıklıkla vurgulandığı söylenmese de toplum bağlamında bu durum özümsendiği ve içselleştirildiği için reklam içeriklerinde erkek ve güç olguları harmanlanmaya devam etmektedir.

Reklamlarda erkek temsili ele alınırken güç simgesinin yanı sıra erkeğe farklı roller ve fikirler de biçilmektedir. Bunlardan birisi erkeğin duyarsız ve bencil tavrının öne çıkarılmasıdır. Örneğin teknoloji ürünleri ve otomobil reklamlarında erkek yalnızca kendi dünyasına çekilmiş ve ürüne odaklanmış olarak sunulur. Dolayısıyla çevreyle olan iletişiminden soyutlanarak kendi tutkularına yöneldiği bir imaj durumu ortaya çıkarılır (Vigorito, 1998:2). Bu kapsamda değerlendirildiğinde bir önceki temsilinin aksine sorumluluktan ve aile ilişkilerinden uzak bir erkek modeli ortaya çıkarılmakta ve eril özelliklerden ziyade ürüne odaklanılması amaçlanmaktadır. Böylece reklam içeriğinde tutku metaforu öne çıkarılarak toplumsal cinsiyet algısı ikinci plana itilmektedir. Ve ayrıca 
küreselleşen dünyada erkek kimliğinin temsili özellikle iş dünyasında öne çıktığı için güçlü devletlerle baş edecek kadar küresel anlamda söz sahibi olan büyük şirketlerde erkeğin sunumu etkin ve güven veren bir bakış açısıyla paylaşılmaktadır. Bu erkek modeli uluslar arası iş erkekliği olarak kabul edilebilecek bir hegemonik erkeklik durumunu teşkil etmekte ve bu doğrultuda kapitalizmin hem iş dünyasındaki hem de medya alanındaki uzantısı olarak yeni bir erkek imajı oluşmaktadır (Connell ve Wood, 2005:48). Yeni bir erkek kimliği inşa eden bu imaj özellikle kurum reklamlarında izleyiciye sunulmakta ve kapitalizmin izleri bu reklamlarda hissedilmektedir.

Öte yandan ekranlardaki reklam sunumlarında kadın temsilinin ne yazık ki cinsel bir obje olarak sunulmasına sıklıkla rastlanmaktadır. Toplum algısı önemsenmeden hedefe yönelik olarak kullanılan bu temsil mantığı kısmen de olsa erkek kimliğinin sunumunda da görülebilmektedir. Dolayısıyla reklamlarda çıplak olarak gösterilen erkek modeli genel olarak yine çıplak olan kadın modeliyle birlikte aktarılmaktadır (Uğur ve Şimşek, 2004:557). Bununla birlikte erkek kimliğinin reklamlarda temsilinde güç olgusunun içeriği olarak işinde başarılı ve karizmatik erkek modeli tercih edilmektedir. Para kazanan bir figür imajının sergilendiği bu reklamlarda erkek hep başarılı ve mutlak otoriter olarak yansitılmaktadır (Roland, 1986:203). Bu reklamlarda eril sunum yapilırken siyah renk imgesi de öne çıkarılmaktadır. Nitekim iletişimde renklerin dili bağlamında siyah renk gücü ve otoriteyi temsil ettiğinden siyah ve erkek ikilisini reklamlarda siklıkla görmek mümkündür. Özellikle de ofis dekorunda, kıyafette, saatte, çantada ve arabada siyahın gösterişi izleyiciye sunulmakta ve erkek ve güç öğeleri renksel iletişimin de yardımıyla ilişkilendirilmektedir.

Reklamlarda toplumsal cinsiyet sunumu gerçekleştirilirken toplumun tutum ve düşüncelerinden ziyade reklamın etki alanı ve bu etki sonucunda elde edilen nihai veriler önem arz etmektedir. Bu bağlamda kurgusal hamleler devreye girdiği için kitleye ulaştırılan reklam içeriklerinde halkın reel yaşamından farklı bir dünyanın anlatıldığı görülebilmektedir (Browne, 2005:92). Bu farklı dünyadaki cinsiyet temsilleri sanallıktan öteye gidemediği için erkek ve kadın modellerinin yanına üçüncü bir sanal modelin yerleştiğini söylemek mümkündür. Zira tamamen kurgusal olan bu modeller gerçeklik payı taşımadığı için yalnızca ürünün ya da hizmetin pazarlanmasında aracı bir konumu üstlenmekle yetinmektedir. Diğer taraftan medya ortamındaki erkek kimliğinin temsili incelenirken araştırmacılar tarafından erkekliğin reklamlarda ve diğer medya araçlarındaki konumu değerlendirilerek hegemonik erkekliğin görünümü ve inşa süreci analiz edilmiştir (Erdoğan, 2011). Neticede başarılı bir kadın temsilinde dahi egemen bir erkek modelinin varlığına dikkat çekilmiş ve reklamlardaki ürün veya hizmetlerin pazarlanması sürecinde hegemonik erkek imajı sılklıla verilmeye devam etmiştir

Reklamlardaki baskın ve egemen erkek imajı neredeyse yarım asırdan da uzun bir zaman önce dahi yine geleneksel değerler bağlamında yaklaşılarak öne çıkarılmıştır. Nitekim 1950'li yıllarda Amerika Birleşik Devletleri'nde izleyiciye sunulan ödüllü reklamlarda erkeğin temsili daha fazla verilmektedir. Elde edilen sonuçlar incelendiğinde reklamlarda erkeklerin \%57 oranında var olduğu ortaya çıkmıştır ve ilginç olan şudur ki kadınlara hitap eden reklam içeriklerinde bile erkek kimliğinin temsili sağlanmıştır (Yüksel 2006:117). Bu bağlamda odaklanılması gereken nokta erkek temsilinde toplumsal yapının ölçüt alınması ve topluma göre hareket edilmesidir. Günümüzde bu durum kısmen de olsa değişmiştir. Çünkü toplumun yargılarından ziyade reklamın ekonomik olarak başarıya ulaşıp ulaşmadığı kıstas alınmaktadır. Küresel sermaye gruplarının etkin olduğu medya sektöründe reklam pastasındaki payın oldukça yüksek olduğu düşünüldüğünde gerek reklam 
verenler gerekse medya patronları reklam içeriği yerine reklamın elde edeceği mali sonuçlara odaklanmaktadır. Ve böylece reklamcılık sektöründe yaşanan hızlı gelişim ve değişimler tamamen bu amaç doğrultusunda gerçekleşmektedir.

Medya ortamında önemli bir kırılma noktası olarak kabul edilen 1990'lı yıllarla birlikte devlet eliyle yürütülen resmi yayıncılığın yerini özel yayıncılık almaya başlamış ve bununla birlikte yeni iletişim teknolojilerinin kullanımına kısmen de olsa artık geçilmeye başlanmıştır. Küresel ticari medya sistemini geliştiren bu süreç geleneksel medyanın hakimiyetini kırarak yeni bir dönüşümü ortaya çıkmıştır (McChesney, 2003:20). Yaşanan bu dönüşüm ile birlikte kamu yayıncılığındaki disiplinli ortamın aksine reklam sunumlarında daha serbest bir ortam ortaya çıktığından dolayı hem sunum hem de içerik olarak reklam alanında magazinsel bir dönüşüm yaşanmıştır. Nitekim reklamlardaki erkek temsilinde özel yayıncılıkla birlikte magazin dünyasının ekranlarda daha fazla tercih ettiği erkek modellerin reklam yüzü olarak kullanılması tercih edilmiştir. Böylece reytingi yüksek erkek profili mantığı ortaya çıkarılarak kitleyi doğrudan etkileme amacı güdülmeye başlanmıştır.

Bununla birlikte medya alanında dünyadaki gelişmelerden sonra Türkiye'de de özellikle 1990'lı yıllarla birlikte televizyon alanında özel yayıncılığa geçilmiş ve böylece içerik olarak magazinleşme dönüşümü yaşanmıştır. Dolayısıyla serbest piyasa ortamında reklam pastasının sunduğu devasa ekonomik getirinin talipleri serbest piyasa zihniyetinin aksine çok daha sınırlı olmuş ve küresel güç sahipleri medya alanında da söz sahibi olduğundan tekelleşme sürecine girilmiştir. Böylece medya ortamı önemli bir güç teşkil etmeye başlamıştır (Mora, 2008:10). Hem dünyada hem Türkiye'de hakim bir güç konumuna erişen medya ortamında reklamların önemi bir kat daha arttığı için bu ekonomik dayanağın daha da ilgi çekici hale getirilmek amacıyla reklam içeriklerindeki sunumlarda gelenekçi anlayışın yerini değişken ve modern bir anlayış almaya başlamıştır. Bu bağlamda yakın tarihe kadar sürekli olarak güçlü ve başarılı bir erkek, bir baba rolüyle reklamlarda temsil edilen erkek kimliği artık bu kalıbın dışına çıkarılarak yeni sunumlarıyla kitleye aktarılmıștır.

\section{Televizyon Reklamcılığında Erkek Kimliğinin Temsiline İlişkin İçerik Analizi}

\subsection{Analizin Amacı ve Kapsamı}

Medya sektörünün reklam yayıncılığı bağlamında en etkin araçlarından birisi olan televizyon alanında reklam içeriklerindeki toplumsal cinsiyet sunumları irdelenerek erkek kimliği temsilinin nasıl inşa edildiğinin tartışıldığ çalışmada, analiz kısmı için 1990 ve 2000 yılları arasındaki televizyon reklamları ölçüt kabul edilerek erkek kimliğinin nasıl ele alındığını tespit etmek amaçlanmıştır.

$\mathrm{Bu}$ doğrultuda analizin kapsamını; eril nitelikleri genel anlamda yansıtan ve bu nitelikleri önemli oranda ele alan iki reklam çözümlemesi oluşturmuştur.

\subsection{Analizin Modeli ve Yöntemi}

Literatür bölümünde genel tarama modelinin uygulandığı çalışmada verilerin değerlendirildiği kısım için içerik analizi tercih edilmiş ve elde edilen bulgular irdelenerek tartışılmıştır.

\subsection{Analizin Evreni ve Örneklemi}

Reklamlardaki erkek kimliği temsilinin televizyon alanındaki sunum sürecini ele alan çalışmada analizin evrenini 1990 ve 2000 yılları arasında yayınlanan televizyon reklam filmleri oluşturmuştur. Analiz kapsamında örneklemi ise yine bu yıllar arasında yayınlanmış olan iki televizyon reklamı temsil etmiştir. Bu reklamlardan ilki 1993 tarihli Ali Desidero 
"Derby" tıraş bıçağı reklamıdır. Diğeri de 1995 tarihinde ekranlarda yayınlanan "Renault Clio" otomobil reklamıdır.

\subsection{Analizin Bulguları}

Çalışmanın içerik analizi kısmında örneklem olarak ele alınan reklamlardan ilki 1993 yılında yayınlanmış olan bir tıraş bıçağı reklamıdır. 58 saniye süreye sahip olan reklamda "Derby - Tek" adlı tıraş bıçağının reklamı Ali Desidero isimli maço olarak kabul edebileceğimiz bir erkek karakterin temsiliyle gerçekleşmiştir.

"Kalite katmerli fiyat yüzde elli sapına kadar derby" sloganıyla ekranlarda boy göstermiş olan "Derby-Tek" tıraş bıçağı reklamı doğrudan erkeklere yönelik olan bir reklam olarak karşımıza çıkmaktadır. Nitekim reklamdaki figüran oyuncular da dahil tüm ekip erkeklerden oluşmakta ve diğer bir çok reklamın aksine hedef kitle kadar reklam kurgusu da erkekleri kapsamaktadır. Erkek kimliğinin maço tarafına odaklanılan bu reklamda verilen mesaj, ürünün gerek fiyat gerekse kalite olarak özgün olduğunu aktarmaya ilişkindir. $\mathrm{Bu}$ özgünlüğü vurgularken ürünün erkekte önemli değiş̧im oluşturacağı imajı aşılanmakta ve diğer markaların yarı fiyatına olması sebebiyle tercih edilmesi gerektiği vurgulanmaktadır.

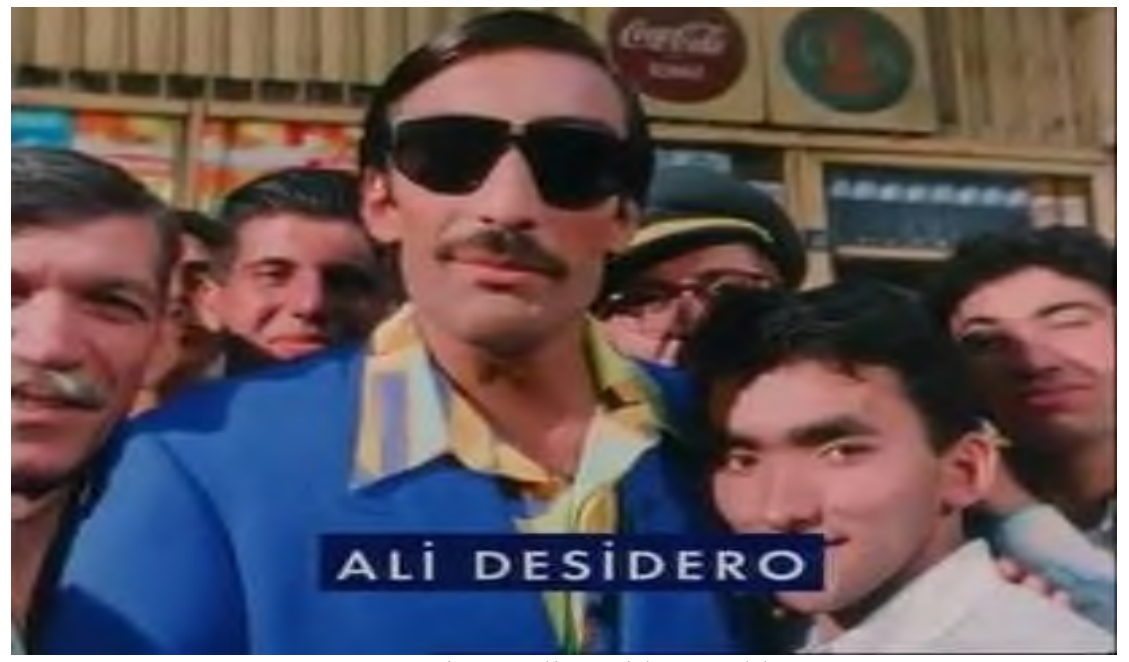

Resim:1 Ali Desidero Reklamı

Kaynak: https://www.youtube.com/watch?v=GiN7UDSwZ9Q

Reklamda dikkat çeken önemli nokta gelenekçi ve yenilikçi yaklaşımı harmanlamış olması durumudur. Öyle ki toplum içerisinde sözü geçen bir "ağabey" modeliyle Ali Desidero isimli karakter, tanıtımı yapılan tıraş bıçağını değerlendirip onaylayan bir üst makam olarak sunulmuş ve etrafındaki erkekler onun tasdikinin akabinde ürünü almayı uygun görmüşlerdir. Bu mantalite, reklam - toplum ilişkisinin tabiatına uygundur ve dünya genelinde televizyonlarda yayınlanan ilk reklamlarda genel olarak bu algı yansıtılmıştır. Reel bir işleyişi aktaran bu algı kurgudan uzak ve gelenekçi bir mizanseni ortaya koymaktadır. Dolayısıyla reklamda erkek kimliğinin temsili inşa edilirken erkeğin toplum içindeki en doğal hali yansıtılarak hedef kitleye bir nevi samimiyet mesajı verilmiş ve aynı zamanda tıraş olmanın bir değişim faktörü olması vurgulanarak yenilikçi algı ortaya çıkarılmıştır. 
Bununla birlikte reklam içeriğinde ürünün fiyatına sıklıkla vurgu yapılmış olması erkeğin ekonomik olarak da gücün simgesi olduğunun aktarılmak istenmesidir. Zira gelenekçi yaklaşımda erkek hem eş hem de baba olarak evin reisidir ve paranın kaynağı da odur. Böylece erkeğin toplum içerisinde erkek gibi algılanabilmesinin en önemli dayanağı ekonomik gücüdür. Erkek ve güç olguları arasındaki kilit nokta para olarak kabul edildiği için erkek cebini düşünmek zorundadır. Bu reklamda da "cebini düşün” mesajı verilerek hedef kitleye hitap edilmiştir.

Reklamın esas teması bu noktadan sonra ortaya çıkmaktadır. "Erkek, toplum içerisinde güç ve güven teşkil eden durumunu korumalı ve bunun yanı sıra erkeksi özelliklerinden de taviz vermemelidir ve ayrıca değişim yani yenilik erkeğin gücünden bir şey kaybettirmediği gibi oluşturduğu farklılıkla hem güçlü hem bakımlı erkek imajını sergiler" mesajı sunulmaktadır. Bu bağlamda reklam kurgusunda erkek kimliği inşa edilirken bakımlı ve değişken imajın aslında eril gücün bir dayanağı olduğu düşüncesi özümsenmiş ve paylaşılmıştır.

Son olarak tıraş bıçağı içeriğiyle kurgulanan bu televizyon reklamının oyuncusundan hedef kitlesine, seslendirmesinden kullanılan müziğine kadar her aşamasında erkek'lik vurgusunun yapılması, sloganında da ifade edildiği gibi sapına kadar bir erkek reklamını ortaya çıkarmış ve izleyiciye sunmuştur.

Örneklem bağlamında ele alınan bir diğer içerik ise "Renault Clio" otomobilinin tanıtımının yapıldığı 46 saniyelik televizyon reklamıdır. Bu reklam filminde de bütün oyuncular erkeklerden oluşmaktadır ve hedef kitle olarak erkekler kadar kadınlar da düşünülmektedir. Nitekim tanıtımı yapılan araç ifade edilirken konforlu olduğuna vurgu yapıldığı esnada pençe gibi kavrama özelliği belirtilerek erkek kitleye, kuğu gibi süzülme niteliği anlatılırken de kadın kitleye hitap etme gayreti güdülmüştür. Bununla birlikte reklam içeriği kurgulanırken keyifli ve güvenilir olma özelliği öne çıkarılarak otomobilin kullanıcılarına aradıkları kombinasyonu sağladığı ve herhangi bir kaygı duymadan kullanabilecekleri mesaj1 verilmiştir.

Reklam filmi incelendiğinde 18 yaş ve üzeri her kesime hitap edildiği anlaşılmaktadır. Zira hem yaşlı hem de genç oyuncuların birlikte tercih edilmesi bu tespiti doğrulamakta ve reklam sloganındaki "büyüklere ne kaldı" ifadesiyle diğer firmalara ve ekonomik yönden zengin kesimlere gönderme yapılmıştır. Öyle ki reklam içeriğinde erkek kimliği temsil edilirken güçlü bir işadamı profili tercih edilmiş ve konforlu otomobil kullanmanın bu profile sahip kişilerle özdeşleştiği imajı doğmuştur. Reklam ilerledikçe bu profile sahip erkek modelinin bahsedilen aracı umursamaz bir tavırla dinlediği görülmüş ve içinde bulunduğu limuzin tipi araç gösterilerek konfor kıyaslamasında adeta bir ironi yapılmıştır.

Reklamı yapılan aracın toplum içerisinde ekonomik olarak vasat sayılabilecek kesime hitap etmiş olduğu değerlendirildiğinde içerik bağlamında sıklıkla vurgulanan "büyüklerde ne varsa onda da var" ifadesi hedef kitleyi etkileme amacının dışa yansımasıdır. $\mathrm{Bu}$ amacı gerçekleştirmek için erkek kimliği titizlikle kullanılmıştır. 


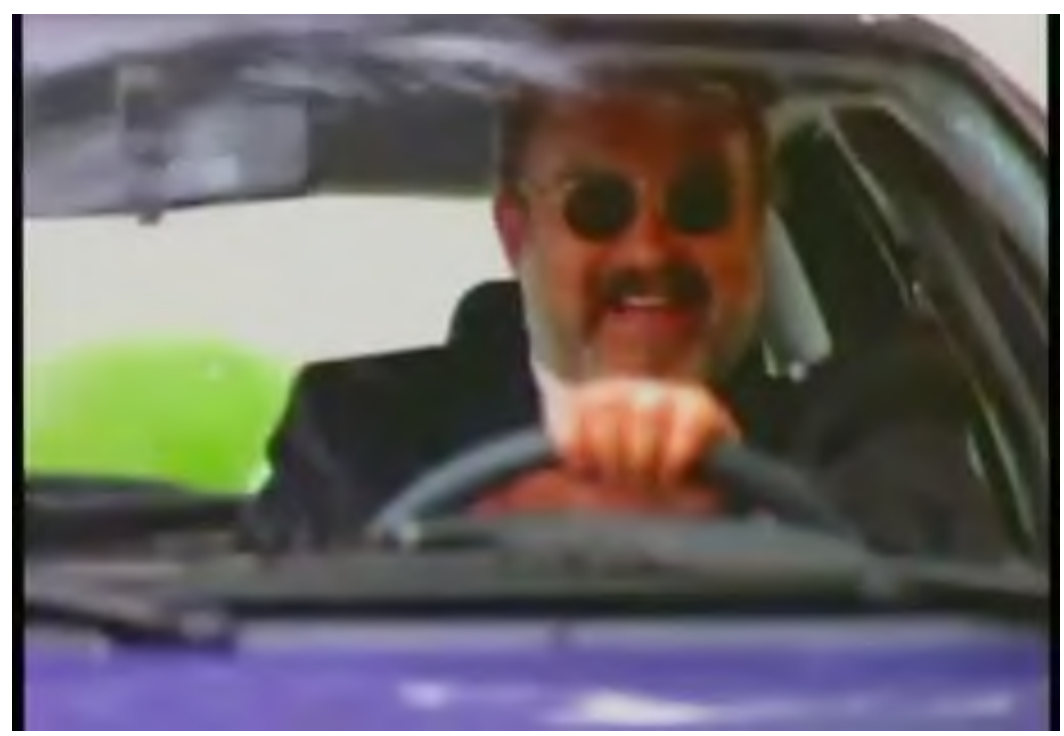

Resim:2 Renault Clio Reklamı

Kaynak: https://www.izlesene.com/video/renault-clio-vs-limuzin/8409079

Dolayısıyla zengin ve güçlü erkek tipi kullanılarak aracın gerek yaşamında değişiklik isteyen orta kesimdeki erkeklere gerekse gücün monotonluğundan sıkılmış zengin tabakadaki erkeklere mesaj verdiği görülmektedir. Bu mesaj verilirken aracı kullanan erkek tipinin sürekli olarak gülmesi ve eğlenmesi, erkek izleyicilere mutluluğun değişimde ve yeni konforlarda olduğunu vurgulamak içindir. Zira televizyon reklamlarında erkek kimliği inşa edilirken özellikle futbol ve araba konularında erkeğin adeta kendinden geçtiği ve bireysel düşündüğü kanaati öne çıkarılmaktadır. Toplumsal gözlemler sonucu kurgusal değil gerçek örneklere dayandırılan bu bakış açısı erkeğin de kendine özgü tutkuları ve beklentileri olabileceğinin göstergesidir.

Bu kapsamda değerlendirildiğinde gerek örneklem olarak ele aldığımız bu otomobil reklamında gerekse erkek kimliğiyle erkeğe yönelik olan diğer reklamlarda hedef kitleyi temsil eden tüm erkeklere, kendi güçlerinin farkında olmaları ve bu gücü kullanmak için mutlu olmaları gerektiği vurgusu yapılmaktadır. Hem mutlu olmak hem de etrafına bu mutluluğu yansıtmak için de gerektiğinde tutkularının peşinden gitmesi düşüncesi aşılanmaktadır. Televizyon reklamları bu mesajı aktarmak için çok etkin bir araçtır ve böylece bu reklamlar ile erkeğe değişime açık ol mesajı verilmektedir.

"Renault Clio" reklamında da bu değişimin otomobil ile gerçekleşeceği iletisi aktarılmış ve "yaşanacak otomobiller" sloganıyla bu hedef perçinlenmiştir. Genel bağlamda değerlendirildiğinde reklam içeriğinde erkek kimliği inşa edilirken erkeğin her ne kadar güçlü ve olgun olsa da içerisinde aktif heyecanlar barındırdığı imajı gösterilmiş ve tutkularıyla baş başa kalan erkeğin mutlu olmayı başarabildiği resmedilmiştir.

\section{SONUC}

Medya çatısı altında televizyon reklamlarındaki erkek kimliğinin nasıl inşa edildiğinin incelendiği bu çalışma neticesinde de ortaya çıkarıldı̆̆g gibi özellikle 2000 ve öncesi dönemlerde erkek kimliği, genel olarak otoritenin ve saygınlığın simgesi olmuştur. 
Dolayısıyla reklam içeriklerinde erkek kimliğinin sunumu yapılırken aile reisi, iş adamı, toplumda söz sahibi kişi gibi roller biçilerek kurgusal süreç tamamlanmıştır. Bunun yanı sıra kendi hobileri ve tutkularının da var olduğu imajını sergilemek amacıyla reklam içeriklerinde erkek kimliği bu yönüyle temsil edilmiş ve pazarlaması yapılacak olan reklam ürünü ya da hizmeti erkek objesiyle bütünleştirilmiştir. Bu bağlamda analiz kısmında ele alınan otomobil reklamını bu imaj için örnek göstermek mümkündür. Nitekim toplum içerisinde sorumluluk ve fedakarlık özellikleriyle öne çıkarılan erkek kimliği yeri geldiğinde kendi tercihlerini de hayata sürmeli ve mutlulukla bağdaşlaştırılan bu algıyı ertelememelidir mesajı reklam senaryolarında dikkate alınmıştır. Özellikle 1990'lı yıllarda tercih edilen bu reklam içeriklerinde erkek kimliğinin farklı biçimlerde temsil edildiği görülmüştür. $\mathrm{Bu}$ dönemin televizyon reklamlarını özgün k1lan husus ise kurgudan uzak ve toplumsal gerçeklere dayandırılan bir çizginin izlenmesi olmuştur. Zira 2000 ve sonrası yıllarda küresel güç sahiplerinin medya sektöründe daha etkin olarak öne çıkmasıyla reklam içeriklerinde toplumun profili ikinci plana atılmış ve popüler kültür baz alınarak mali getirisi yüksek kurgular tercih edilmiştir.

Sonuç olarak; globalleşen dünyada medya alanı giderek gelişim gösterdiği gibi özellikle teknolojik bakımdan değişim de yaşamıştır. Kitle iletişim araçlarının en etkin güce sahip organlarından birisi olan televizyon yayıncılığı ise geleneksel medyada olduğu gibi değişim ile birlikte dijitalleşen yeni medya sürecinde de etkinliği ve cazibesini geliştirerek sürdürmeye devam etmiştir. $\mathrm{Bu}$ doğrultuda toplumsal cinsiyetin sunumu açisından televizyon reklamcılığının varlığ önemini korumaya devam etmiş ve böylece gerek erkek kimliğinin temsilinde gerekse kadın kimliğinin sunumunda reklam içerikleri televizyon bağlamında yeni medya süreciyle de beraber dönüşümünü kitleye yansıtmıştır. Dönüşüm sürecine entegre olmakta güçlük çekmeyen televizyon yayıncılığg bu aktif ve yaygın durumuyla konvansiyonel medya alanında olduğu gibi yeni iletişim teknolojileri alanında da reklamcılık sektörü için önemini sürdürmüştür.

\section{KAYNAKÇA}

ANTHONY, V. (1998) "Marketing Masculanity:Gender Identity and Popular Magazines", Sex Roles: A Journal of Research, July.

APAK, K. H., KASAP, F. (2014) "Türk Televizyonlarındaki Gida Reklamlarında Kadın Ve Erkek Imgesi Üzerine Bir Inceleme. Uluslar arası Sosyal Araştırmalar Dergisi. Cilt 7 Sayı 34

BERGER, P. L., LUCKMANN, T. (2008) "Gerçekliğin Sosyal İnşâsı, Bir Bilgi Sosyolojisi İncelemesi”, Çev. Vefa Saygın Ögütle, İstanbul, Paradigma Yayınları.

BİLGiN, N. (1994) "Sosyal Bilimlerin Kavşağında Kimlik Sorunu” , İzmir: Ege Yayincilik.

BİLGIN, N. (2000). “Íçerik Analizi”,. Ege Üniversitesi Edebiyat Fakültesi Yayınları: İzmir.

BROWNE, K. (2005) “An Introduction to Sociology”, Cambridge: Polity Press.

BURTON, G. (1995). “Görünenden Fazlası: Medya Analizlerine Giriş”, Çev. N. Dinç, İstanbul: Alan Yayıncılık.

CONNELL, R., WOOD, J. (2005). “Globalization and Business Masculinities. Men and Masculinities."

DEANA, R. (2002) "Eroticizing Men: Cultural Influences on Advertising and MaleObjectification-1", Sex Roles: A Journal of Research, February. 
DEMIR, N. K. (2006) "Kültürel Değişimlerin Reklamlarda Kadın ve Erkek RolModellerine Yansıması", Firat Üniversitesi Sosyal Bilimler Dergisi, Cilt: 16, Sayı: 1.

DÜNDAR, Ö. Z. (2012) "Toplumsal Cinsiyet Rollerinin Televizyon Reklamlarina Yansıması" Ethos: Felsefe Ve Toplumsal Bilimlerde Diyaloglar Ocak , 5(1), 121136.

ELDEN, M. (2004) “Reklam Yazarlı̆̆ı”, İletişim Yayınları, İstanbul,

ERDOĞAN, İ. (2011). "Medyada Hegemonik Erkek(lik) ve Temsil” İstanbul: Kalkedon Y.

HARWEY, D. (1999). "Postmodernliğin Durumu: Kültürel Değişimin Kökenleri”. (Çev.: Sungur Savran). İstanbul: Metis.

KARPAT, K. (1987) “Kimlik Sorusunun Türkiye’ deki Tarihi, Sosyal ve Ídeolojik Gelişmesi” Türk Aydını ve Kimlik Sorunu , İstanbul: Bağlam Yayınları.

KAUFMAN, G. (1999) “The Portrayal of Men's Family Roles in Television Commercials", Sex Roles: A Journal of Research, Vol. 41.

KOCABAŞ, F., ELDEN M. (2004) “Reklamcıllk- Kavramlar, Kararlar, Kurumlar,” İletişim Yayınları, İstanbul.

LULL, J. (2001) “Medya, Illetişim ve Kültür” Ankara: Vadi Yayınları.

MCCHESNEY, R. (2003). "Küresel Illetişimin Politik Ekonomisi” Robert W. McChesney, Ellen Meiksins Wood vd. (Ed.), Kapitalizm ve Enformasyon Çăğ, N S Çınga vd. (Çev.), Ankara: Epos Yayınları.

MORA, N. (2008) “Medya ve Kültürel Kimlik” Uluslararası İnsan Bilimleri Der. Cilt:5 Sayı:1

NALÇAOĞLU, H. (2003), "Medya ve toplum Ilişkisini Anlamak Üzere Bir Çerçeve", Sevda Alankuş (Der.), Medya ve Toplum, İstanbul: IPS İletişim Vakfi Yayınları.

OWENS, T. (2006). "Self and Identity". Delamater, J. (der.). Handbook of Social Psychology içinde. New York: Springer, 205-232.

ÖZDEMIR, M. (2010) “Türkiye'deki Reklâmlarda Toplumsal Cinsiyet ve Sunumu”. Milli Folklor Y11 22 Say1 88.

ROLAND, M. (1986). “Advertising the American Dream”, University of California Pres, California, USA.

SABUNCUOĞLU, A. (2006). "TV Reklamlarında Toplumsal Cinsiyet" Yüksek Lisans Tezi "Ege Üniversitesi Sosyal Bilimler Enstitüsü Halkla İlişkiler Ve Tanıtım Anabilim Dalı".

TAŞYÜREK, N. (2013). "Reklam ve Reklamın Tüketicilerin Satın Alma Davranışları Üzerindeki Etkisi: Bir Alan Araştırmast."

Tímisí, N. (2004). "Reklamların Kadınlar Üzerindeki Etkileri:”, "Reklamların İzleyiciler Üzerindeki Etkileri” Paneli, RTÜK Yayın No:10, 1.Bask1, Ankara.

TURNER, J. (2010). “Towards a Cognitive Redefinition of Social Group." Tajfel, H. (der.). Social Identity and Intergroup Relations içinde. Cambridge: Cambridge University Press.

UĞUR, İ., ŞİMŞEK, S. (2004). "Kitle İletişim Araçlarındaki Reklamlarda Kadın ve Erkek Objelerin Kullanılması”, Selçuk Üniversitesi Sosyal Bilimler Enstitüsü Dergisi, Sayı: 11

USLU, Z. K. (2000). “Televizyon ve Kadin.” İstanbul: Alfa.

VAROL, S. F. (2014). "Medyada Yer Alan Temsillerin Kimlik Edinme Sürecindeki Rolü” International Journal Of Social Science Number: 26, P. 301-313, Summer II

WILliAMSON, J. (2001). "Reklamların Dili: Reklamlarda Anlam ve Ídeoloji" Çev. Ahmet F. Ütopya Yayınları. İstanbul. 
WOODWARD, K. (1997). "Concepts of Identity and Difference”. Woodward, K.(der.). Identity and Difference içinde. Kathryn Woodward. Londra.

YAVUZ, Ş. (2007). "Reklamları İzlediniz: Reklamların Farklı Okumalarına Dair Bir Çalışma”. Ankara. Ütopya Yayınevi.

YÜKSEL, A. (2006). "Otomobil Reklâmlarında Yerleşik Toplumsal Cinsiyet Kalıpları: Türkiye'de Yayınlanan TV Reklâmları Üzerine Bir Çalışma”, Konya: S.Ü. İletişim Fak. Yayınları, Ocak, C.4, Sayı.2.

İnternet Kaynakları:

https://www.youtube.com/watch?v=GiN7UDSwZ9Q Erişim Tarihi: 17.02 .2016 https://www.izlesene.com/video/renault-clio-vs-limuzin/8409079 Erişim Tarihi: 18.02.2016 